\title{
THE EFFECT OF SILVER ADDITION ON MICROSTRUCTURE AND THERMAL PROPERTIES OF THE Cu-10\%AI-8\%Mn SHAPE MEMORY ALLOY
}

\author{
Dragan Manasijevic ${ }^{\prime *}$, Ljubiša Balanović ${ }^{1}$, Tamara Holjevac Grgurić ${ }^{2}$, Urǒ́ \\ Stamenkovićl, Duško Minić, ${ }^{3}$,Milena Premović ${ }^{3}$, Radiša Todorović, ${ }^{4}$, Nada \\ Štrbac ${ }^{1}$, Milan Gorgievski ${ }^{1}$, Mirko Gojić ${ }^{2}$, Emi Govorčin Bajsic ${ }^{5}$ \\ ${ }^{1}$ University of Belgrade, Technical Faculty, Bor, Serbia \\ ${ }^{2}$ University of Zagreb, Faculty of Metallurgy, Sisak, Croatia \\ ${ }^{3}$ University of Priština, Faculty of Technical Sciences, \\ Kosovska Mitrovica, Serbia \\ ${ }^{4}$ Institute of Mining and Metallurgy, Bor, Serbia \\ ${ }^{5}$ University of Zagreb, Faculty of Chemical Engineering and Technology, \\ Zagreb, Croatia
}

Received 18.09.2017

Accepted 26.09.2017

\begin{abstract}
The influence of $\mathrm{Ag}$ addition on microstructure and thermal properties of the $\mathrm{Cu}$ $10 \% \mathrm{Al}-8 \% \mathrm{Mn}$ alloy was investigated in this work. Two alloys with designed compositions $\mathrm{Cu}-10 \% \mathrm{Al}-8 \% \mathrm{Mn}$ and $\mathrm{Cu}-10 \% \mathrm{Al}-8 \% \mathrm{Mn}-4 \% \mathrm{Ag}$ (in wt.\%) were prepared by induction melting of pure metals. Microstructures of the prepared samples were investigated in the as-cast state, after homogenization annealing and after quenching.

The effects of different methods of heat treatment on the microstructure and transformation temperatures of the investigated $\mathrm{Cu}-10 \% \mathrm{Al}-8 \% \mathrm{Mn}$ and $\mathrm{Cu}-10 \% \mathrm{Al}-$ $8 \% \mathrm{Mn}-4 \% \mathrm{Ag}$ alloys were investigated using SEM-EDS and DSC techniques.

It was determined that after induction melting microstructure of the both investigated alloys are primarily composed of martensite and a small amount of $\alpha$-phase precipitates.

Fully martensitic structure in both investigated alloys was obtained after direct quenching from the $850^{\circ} \mathrm{C}$ into the ice water. Based on the DSC cooling curves it was determined that two-step martensite transformation for the both investigated alloys occur in the temperature interval from about 30 to $-40{ }^{\circ} \mathrm{C}$.
\end{abstract}

\footnotetext{
${ }^{*}$ Corresponding author: Dragan Manasijević,dmanasijevic@ttbor.bg.ac.rs
} 
Keywords: Shape memory alloy; Cu-Al-Mn-Ag alloy; Microstructure; Martensitic transformation.

\section{Introduction}

Cu-based shape memory alloys (SMAs) show good shape memory properties, high electrical and thermal conductivity, are easier to produce and process and have lower production cost comparing to Ni-Ti-based SMAs $[1,2]$.

The shape memory effect in the Cu-based SMAs is based on martensitic transformation (MT) which is a diffusionless and reversible solid-state phase transformation [2-4]. It occurs between the high-temperature austenite phase and the low-temperature martensite phase [3-4].

During cooling, the martensitic transformation (MT) occurs at a temperature Ms (martensite start) and continues to evolve until a temperature Mf (martensite finish) is reached. Similarly, during the heating cycle, the reverse transformation (martensite-toaustenite) begins at the temperature As (austenite start) and ends at Af (austenite finish) when the material is fully austenite [2].

$\mathrm{Cu}-\mathrm{Al}-\mathrm{Mn}$ alloys have good shape memory properties, excellent ductility, interesting magnetic properties and they represent commercially attractive $\mathrm{Cu}$-based SMAs [5].

In recent years, many studies have been carried out in order to improve the properties of $\mathrm{Cu}-\mathrm{Al}-\mathrm{Mn}$ systems by adding other elements such as $\mathrm{Ni}, \mathrm{Ti}, \mathrm{Mg}, \mathrm{Fe}[6,7]$.

In this work, the influence of $\mathrm{Ag}$ addition on microstructure and shape memory properties of the $\mathrm{Cu}-10 \% \mathrm{Al}-8 \% \mathrm{Mn}$ alloy was investigated. Two alloys with designed compositions $\mathrm{Cu}-10 \% \mathrm{Al}-8 \% \mathrm{Mn}$ and $\mathrm{Cu}-10 \% \mathrm{Al}-8 \% \mathrm{Mn}-4 \% \mathrm{Ag}$ were prepared by induction melting of pure metals. Microstructures of the prepared samples were investigated in the as-cast state, after homogenization annealing and after quenching using SEM-EDS. Transformation temperatures of the investigated alloys were determined using DSC technique.

\section{Experimental procedure}

Two alloys with designed compositions $\mathrm{Cu}-10 \% \mathrm{Al}-8 \% \mathrm{Mn}$ and $\mathrm{Cu}-10 \% \mathrm{Al}-$ $8 \% \mathrm{Mn}-4 \% \mathrm{Ag}$ were prepared by induction melting of calculated quantities of pure copper (99.99\%), aluminum (99.97\%), manganese (99.95\%) and silver $(99.99 \%)$ in the graphite crucibles under a charcoal cover. The cylindrically shaped ingots $(10 \mathrm{~mm}$ diameter and $30 \mathrm{~mm}$ length) were produced.

Prepared ingots were homogenized at $850^{\circ} \mathrm{C}$ for 5 hours and cooled inside the furnace. After that alloys were subjected to $\beta$-annealing at $850{ }^{\circ} \mathrm{C}$ for 1 hour and quenched with the ice water.

Samples used for the scanning electron microscopy (SEM) observations were mechanically grinded and polished. Subsequently, they were etched with a solution containing $2.5 \mathrm{~g} \mathrm{FeCl}_{3} \cdot \mathrm{H}_{2} \mathrm{O}$ and $1 \mathrm{ml} \mathrm{HCl}$ in $48 \mathrm{ml}$ methanol.

TESCAN VEGA3 scanning electron microscope with energy dispersive spectroscopy (EDS) (Oxford Instruments X-act) was used for microstructure investigation of the prepared alloys and the measurements were carried out at $20 \mathrm{kV}$.

Martensitic transformation temperatures, which are according to the predicted results obtained by using empirical equations from literature close to the room temperature, were studied on DSC analyzer Mettler Toledo 822e. Measurements were 
done in an inert atmosphere, through 2 heating/cooling cycles from -50 to $250{ }^{\circ} \mathrm{C}$ with heating/cooling rates $10^{\circ} \mathrm{C} / \mathrm{min}$.

\section{Calculation of phase equilibria}

Calculation of phase equilibria in the $\mathrm{Cu}-\mathrm{Al}-\mathrm{Mn}$ ternary system was performed using CALPHAD (calculation of phase diagrams) approach $[8,9]$ based on the thermodynamic description published by Miettinen [10], which is valid for the copper rich-side of ternary $\mathrm{Cu}-\mathrm{Al}-\mathrm{Mn}$ phase diagram. Thermodynamic assessment of the quaternary $\mathrm{Cu}-\mathrm{Al}-\mathrm{Mn}-\mathrm{Ag}$ system has still not been published in the literature.

CALPHAD method is based on a calculation of the Gibbs energy of a phase as a function of its composition, temperature, and pressure. Gibbs energy data for all phases appearing in the investigated system are defined as polynomial functions in the thermodynamic database. Calculation of phase equilibria is performed using Gibbs energy minimization software [9].

\section{Results and discussion}

Phase equilibria calculation

In order to predict equilibrium phases for the investigated ternary $\mathrm{Cu}-10 \% \mathrm{Al}-$ $8 \% \mathrm{Mn}$ alloy, calculation of the phase equilibria in the $\mathrm{Cu}-\mathrm{Al}-\mathrm{Mn}$ ternary system was performed using thermodynamic parameters from the thermodynamic assessment of Miettinen [10]. It is important to note that, because of the lack of data, the disorderorder phase transitions of the $\beta$ (Bcc) phase from A2 to B2 and B2 to L21 were not considered in the thermodynamic assessment by Miettinen [10]. However, it is known that during quenching from the $\beta$ phase mentioned alloys undergo the following ordering reactions: $\beta$ (A2) $\rightarrow \beta 2$ (B2) $\rightarrow \beta 1$ ((L21). With further fast cooling, depending on the alloy composition and previous heat treatment, three types of martensite can appear in the microstructure: $\alpha^{\prime}(3 \mathrm{R}), \beta_{1}$ ' (18 R) and $\gamma_{1}$ ' (2H) [11-12].

Fig. 1 shows calculated phase diagram at $850{ }^{\circ} \mathrm{C}$ of the $\mathrm{Cu}-\mathrm{Al}-\mathrm{Mn}$ ternary system using optimized thermodynamic parameters from Miettinen [10] and Pandat software [13] with the marked overall composition of the $\mathrm{Cu}-10 \% \mathrm{Al}-8 \% \mathrm{Mn}$ alloy investigated in this study. 


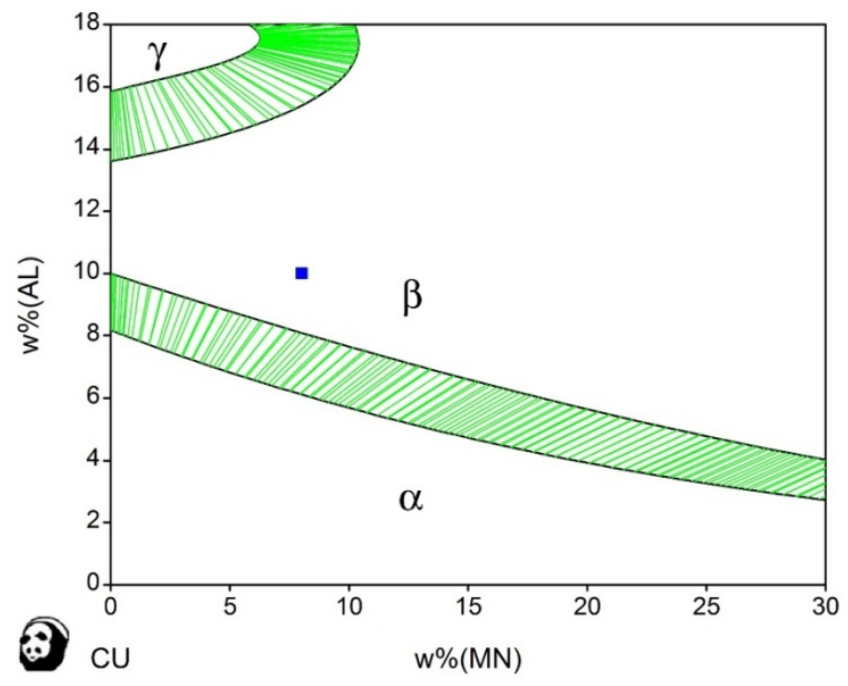

Fig. 1. Calculated phase diagram of $\mathrm{Cu}-\mathrm{Al}-\mathrm{Mn}$ ternary system at $850^{\circ} \mathrm{C}$ with the labeled overall composition of the $\mathrm{Cu}-10 \% \mathrm{Al}-8 \% \mathrm{Mn}$ alloy (square).

According to the calculated phase diagram at $850{ }^{\circ} \mathrm{C}$ shown in Fig. 1, the overall composition of the $\mathrm{Cu}-10 \% \mathrm{Al}-8 \% \mathrm{Mn}$ alloy belongs to phase stability region of the $\beta$ (Bcc) phase. Figs. 2 and 3 show calculated vertical section with 82 wt.\% of $\mathrm{Cu}$ and calculated phase fractions with temperature diagram under equilibrium conditions for the $\mathrm{Cu}-10 \% \mathrm{Al}-8 \% \mathrm{Mn}$ alloy.

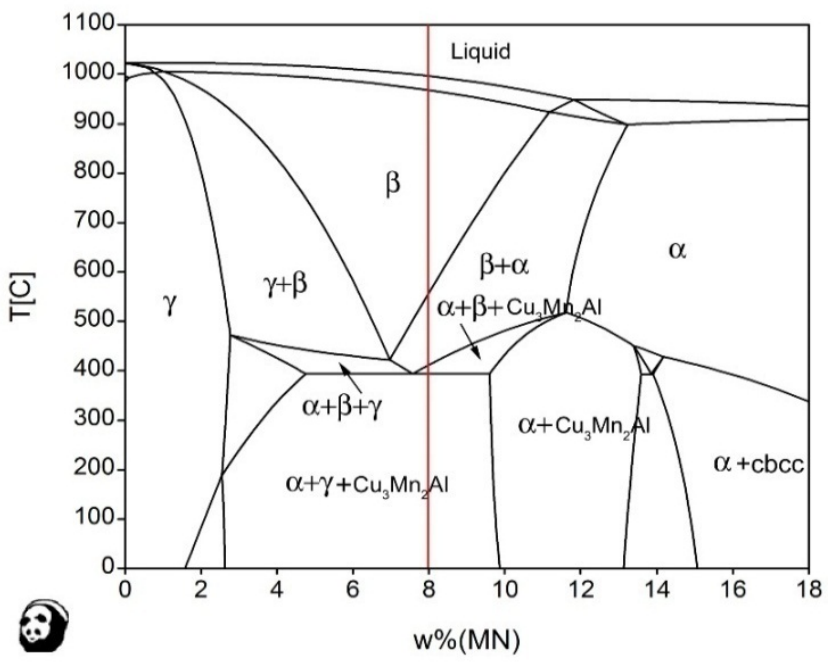

Fig. 2. Calculated vertical section with $82 \mathrm{wt} \%$ of $\mathrm{Cu}$ with the labeled composition of the $\mathrm{Cu}-10 \% \mathrm{Al}-8 \% \mathrm{Mn}$ alloy. 


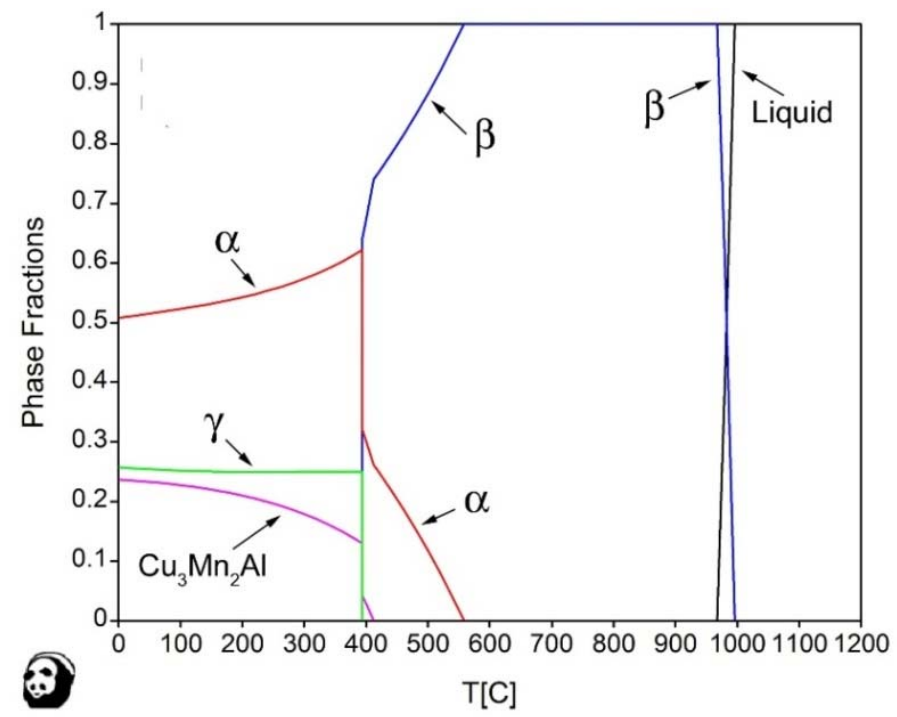

Fig. 3. Calculated phase fractions with temperature diagram under equilibrium conditions for the $\mathrm{Cu}-10 \% \mathrm{Al}-8 \% \mathrm{Mn}$ alloy.

The large stability region of $\beta$-phase can be observed at high temperatures. During the equilibrium cooling the $\beta$ phase undergoes a ternary eutectoid transformation $\beta \leftrightarrow \alpha+\gamma+\tau_{3}\left(\mathrm{Cu}_{3} \mathrm{Mn}_{2} \mathrm{Al}\right)$ at $393{ }^{\circ} \mathrm{C}$. It can also be noticed that under equilibrium conditions, $\tau_{3}\left(\mathrm{Cu}_{3} \mathrm{Mn}_{2} \mathrm{Al}\right)$ ternary phase is a stable phase at room temperature in wide composition interval. However, during fast cooling $\beta$ phase can transform into the martensite phase.

\section{Microstructures of alloys after induction melting}

Microstructures and phase compositions of the $\mathrm{Cu}-10 \% \mathrm{Al}-8 \% \mathrm{Mn}$ and $\mathrm{Cu}-$ $10 \% \mathrm{Al}-8 \% \mathrm{Mn}-4 \% \mathrm{Ag}$ alloys after induction melting were investigated using SEM.

Overall chemical compositions of the investigated $\mathrm{Cu}-\mathrm{Al}-\mathrm{Mn}$ and $\mathrm{Cu}-\mathrm{Al}-\mathrm{Mn}-$ Ag alloys were checked using EDS area analysis. Designed and average overall chemical compositions of the investigated samples obtained by EDS analysis are given in Table 1.

Table 1. Designed and experimentally determined overall compositions of the investigated samples.

\begin{tabular}{ccccccccc}
\hline Sample & \multicolumn{2}{c}{$\begin{array}{c}\text { Designed composition } \\
\text { (wt.\%) }\end{array}$} & \multicolumn{3}{c}{$\begin{array}{c}\text { Experimentally determined composition } \\
\text { with calculated standard uncertainties } \\
\text { (wt.\%) }\end{array}$} \\
\cline { 2 - 9 } & & & & & & $\mathrm{Al}$ & $\mathrm{Mn}$ & $\mathrm{Ag}$ \\
\hline 1 & 82 & 10 & 8 & 0 & $82.6 \pm 0.4$ & $9.7 \pm 0.2$ & $7.7 \pm 0.1$ & 0 \\
2 & 78 & 10 & 8 & 4 & $78.2 \pm 0.4$ & $9.8 \pm 0.2$ & $7.6 \pm 0.1$ & $4.4 \pm 0.2$ \\
\hline
\end{tabular}


As it can be seen from Table 1 there are small deviations between designed and experimentally determined overall compositions for both investigated alloys.

Characteristic SEM micrographs of the investigated bulk alloys after induction melting are shown in Fig. 4.

Based on the obtained results of microstructural analysis it was determined that after induction melting both investigated $\mathrm{Cu}-10 \% \mathrm{Al}-8 \% \mathrm{Mn}$ and $\mathrm{Cu}-10 \% \mathrm{Al}-8 \% \mathrm{Mn}-$ $4 \% \mathrm{Ag}$ bulk alloys have similar two-phase microstructure which includes predominant amount of martensite phase and small $\alpha$ precipitate particles irregularly distributed in and along the boundaries of martensitic grains.

The fine plate- or spear-like martensitic groups (most probably $\beta_{1}$ ' martensite with a monoclinic $18 \mathrm{R}_{1}$ structure) [14-16] are observed in the microstructure of both investigated alloys (Figs. $4 \mathrm{a}$ and $4 \mathrm{~b}$ ).

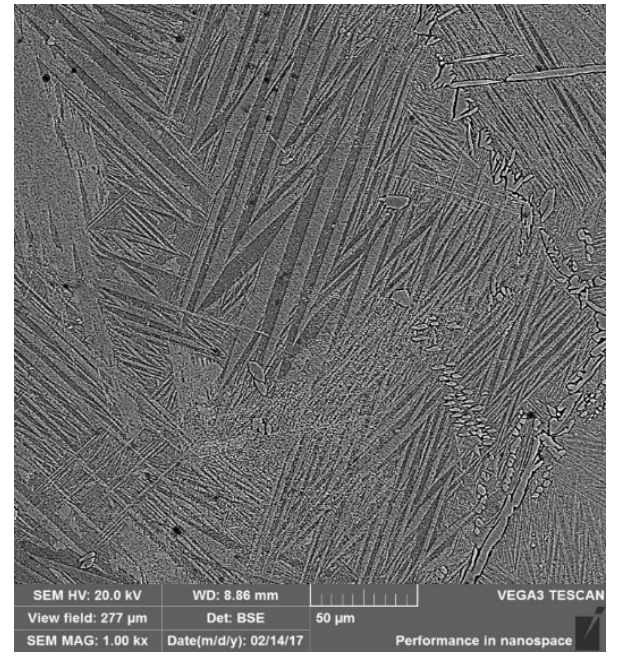

(a)

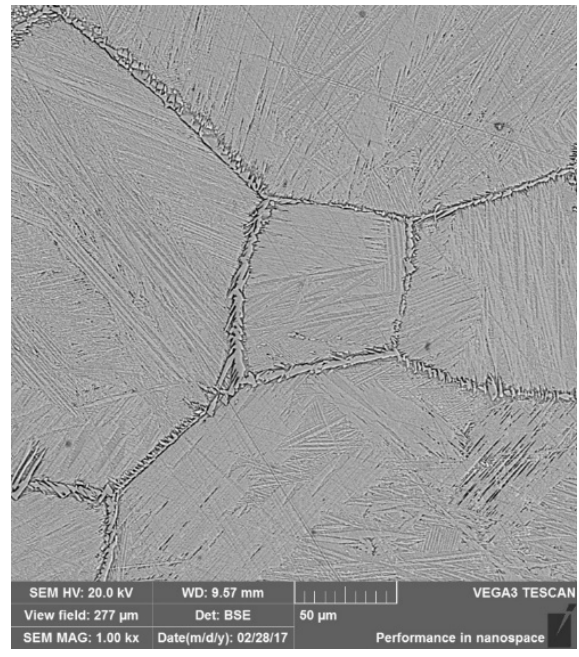

(b)

Fig. 4. SEM micrographs of investigated bulk alloys after induction melting: (a) $\mathrm{Cu}-$ $10 \% \mathrm{Al}-8 \% \mathrm{Mn}$ alloy, (b) $\mathrm{Cu}-10 \% \mathrm{Al}-8 \% \mathrm{Mn}-4 \% \mathrm{Ag}$ alloy.

Microstructures of homogenized alloys

SEM micrographs of the investigated $\mathrm{Cu}-10 \% \mathrm{Al}-8 \% \mathrm{Mn}$ and $\mathrm{Cu}-10 \% \mathrm{Al}-$ $8 \% \mathrm{Mn}-4 \% \mathrm{Ag}$ bulk alloys after homogenization annealing at $850{ }^{\circ} \mathrm{C}$ for five hours and cooling inside the furnace are presented in Figs $5 \mathrm{a}$ and $5 \mathrm{~b}$.

Again, the microstructures of the both investigated alloys were similar and included matrix phase with the lath structure (light phase) and $\alpha$ precipitates (dark phase). 


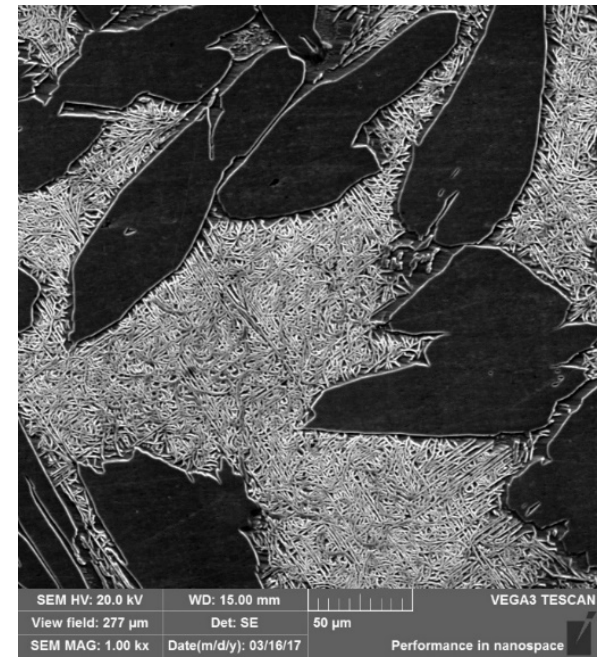

(a)

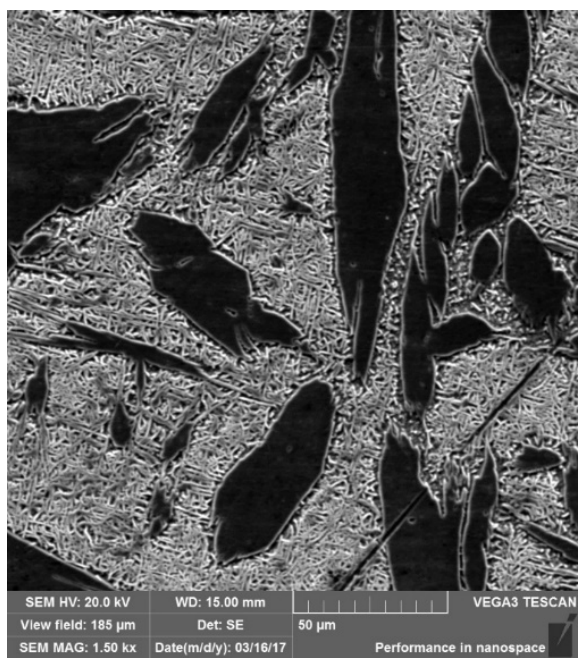

(b)

Fig. 5. SEM micrographs of investigated bulk alloys after homogenization annealing at $850{ }^{\circ} \mathrm{C}$ for 5 hours and slow cooling: (a) $\mathrm{Cu}-10 \% \mathrm{Al}-8 \% \mathrm{Mn}$ alloy, (b) $\mathrm{Cu}-10 \% \mathrm{Al}-$ $8 \% \mathrm{Mn}-4 \% \mathrm{Ag}$ alloy.

Average chemical compositions of identified phases were determined using EDS analysis and shown in Table 2 . The dark phase has a higher amount of copper and lower amount of aluminum than the light matrix phase. The manganese amount is somewhat higher in the light phase in both investigated alloys. In the $\mathrm{Cu}-10 \% \mathrm{Al}-8 \% \mathrm{Mn}-4 \% \mathrm{Ag}$ alloy silver is dissolved in both phases $(4.2 \%$ in the light phase and $2.9 \%$ in the dark phase). It can be concluded that dark phase represents $\mathrm{Cu}$-rich $\alpha$ phase.

Table 2. Chemical compositions of co-existing phases in alloys after homogenization annealing at $850^{\circ} \mathrm{C}$ for 5 hour and slow cooling determined by EDS analysis.

\begin{tabular}{lccccc}
\hline & $\begin{array}{c}\text { Chemical compositions of } \\
\text { phases in homogenized and } \\
\text { slowly cooled bulk alloys } \\
\text { determined by EDS } \\
\text { analysis }\end{array}$ & $\begin{array}{c}\mathrm{Cu} \\
(\text { wt.\%) }\end{array}$ & $\begin{array}{c}\mathrm{Al} \\
\text { (wt.\%) }\end{array}$ & $\begin{array}{c}\mathrm{Mn} \\
\text { (wt.\%) }\end{array}$ & $\begin{array}{c}\mathrm{Ag} \\
\text { (wt.\%) }\end{array}$ \\
\hline $\mathrm{Cu}-10 \% \mathrm{Al}-$ & $\begin{array}{c}\text { Dark phase } \\
\text { Light phase }\end{array}$ & 84.6 & 8.2 & 7.2 & - \\
\hline $\mathrm{Cu}-10 \% \mathrm{Al}-$ & Dark phase & 81.6 & 9.7 & 7.8 & - \\
$8 \% \mathrm{Mn}-4 \% \mathrm{Ag}$ & Light phase & 78.2 & 10.0 & 7.6 & 4.2 \\
\hline
\end{tabular}




\section{Microstructures of the quenched alloys}

Microstructures of the $\mathrm{Cu}-10 \% \mathrm{Al}-8 \% \mathrm{Mn}$ alloy and $\mathrm{Cu}-10 \% \mathrm{Al}-8 \% \mathrm{Mn}-4 \% \mathrm{Ag}$ bulk alloys after quenching were fully martensitic as it is shown in Fig. 6. It should be noticed that the observed bright and dark regions are related to morphology and surface topography of the studied samples and not to the presence of different phases.

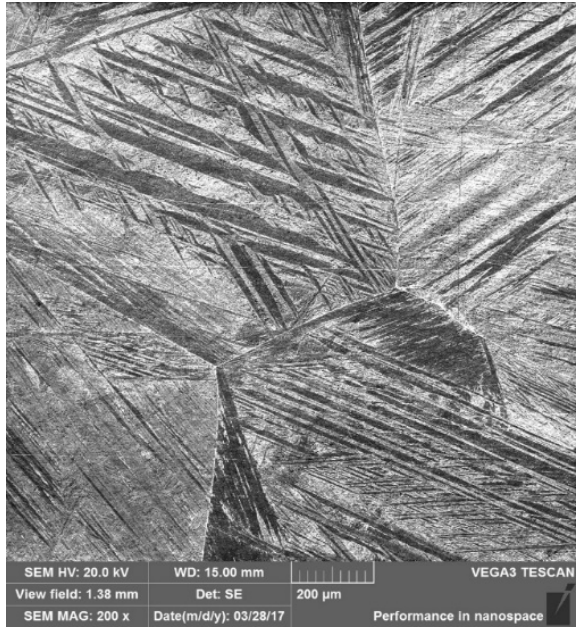

(a)

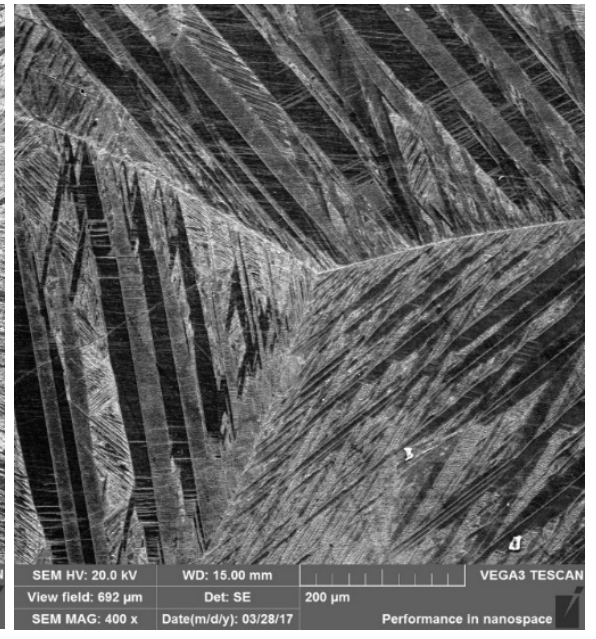

(b)

Fig. 6. SEM micrographs of investigated bulk alloys after $\beta$-solutionizing at $850^{\circ} \mathrm{C}$ for 60 minutes and quenching in the ice water: (a) $\mathrm{Cu}-10 \% \mathrm{Al}-8 \% \mathrm{Mn}$ alloy, (b) $\mathrm{Cu}-$ $10 \% \mathrm{Al}-8 \% \mathrm{Mn}-4 \% \mathrm{Ag}$ alloy.

Morphology of martensitic structure in the as-quenched alloys was somewhat different than after induction melting. Beside the zig-zag martensitic groups, which are characteristic of $\beta_{1}$ ' type of martensite, the microstructure of the both investigated alloys included coarse variants which are characteristic of $\gamma_{1}$ ' martensite (orthorhombic $2 \mathrm{H}$ type) $[14,15]$. The reason for this could be longer holding-time in the parent-phase (after homogenization annealing and $\beta$-solutionizing), which improves the order degree and condition for the formation of $\gamma_{1}$ ' martensite [14].

Martensitic structures of the quenched alloys under larger magnification are presented in Figs. 7a and 7b. 


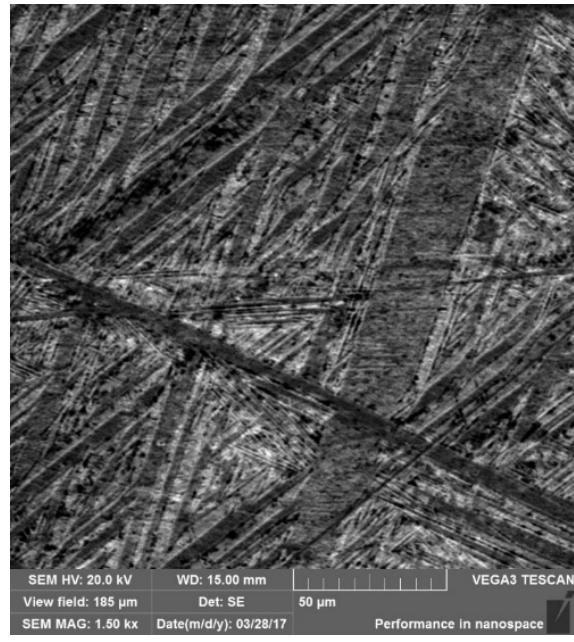

(a)

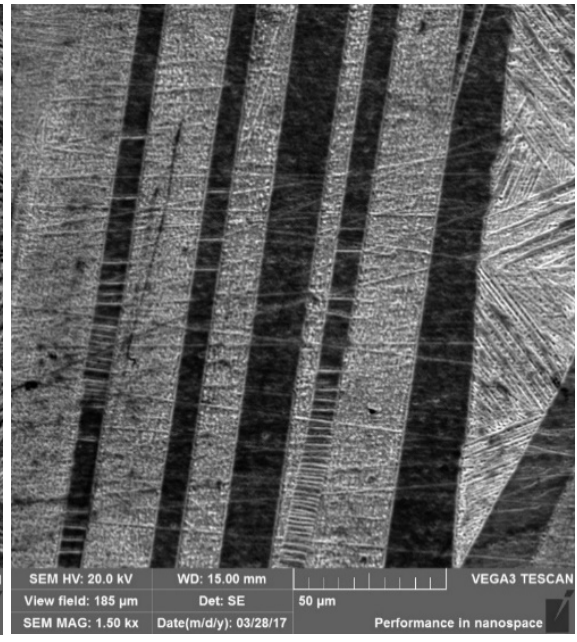

(b)

Fig. 7. Martensitic structure of the quenched alloys: (a) $\mathrm{Cu}-10 \% \mathrm{Al}-8 \% \mathrm{Mn}$, (b) $\mathrm{Cu}-10 \% \mathrm{Al}-8 \% \mathrm{Mn}-4 \% \mathrm{Ag}$.

Experimental investigation of transformation temperatures for the as-quenched alloys

Martensite and reverse martensite transformation temperatures for the $\mathrm{Cu}-10 \% \mathrm{Al}-8 \% \mathrm{Mn}$ and $\mathrm{Cu}-10 \% \mathrm{Al}-8 \% \mathrm{Mn}-4 \% \mathrm{Ag}$ as-quenched alloys were studied using two DSC heating/cooling cycles in the temperature range from -50 to $250{ }^{\circ} \mathrm{C}$. Fig. 8 presents second DSC heating/cooling cycle obtained for the $\mathrm{Cu}-10 \% \mathrm{Al}-8 \% \mathrm{Mn}$ alloy.

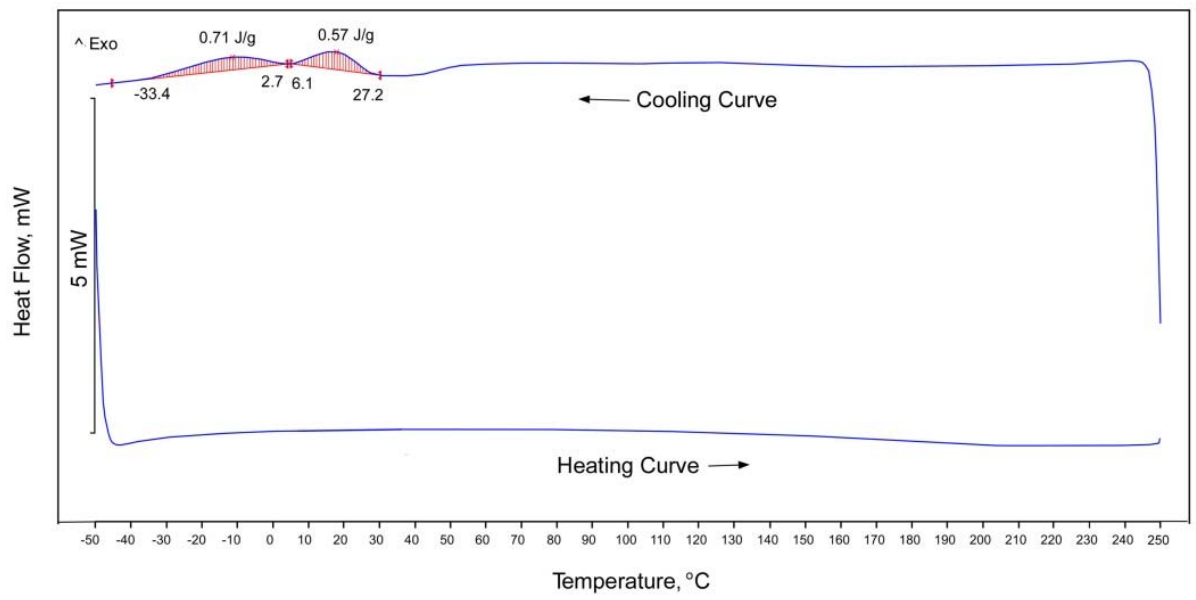

Fig. 8. DSC heating and cooling curves for the as-quenched $\mathrm{Cu}-10 \% \mathrm{Al}-8 \% \mathrm{Mn}$ alloy.

Martensite start temperature (Ms) was obtained as the temperature of the extrapolated peak onset while the martensite finish temperature (Mf) was determined as 
the extrapolated peak endset temperature on cooling. Two distinct successive exothermic peaks in the temperature interval from about $+30{ }^{\circ} \mathrm{C}$ to $-40{ }^{\circ} \mathrm{C}$ were detected during the cooling run (Fig. 8). The onset of the first peak was at $27.2^{\circ} \mathrm{C}(\mathrm{Ms})$ and extrapolated endset of the first peak was $6.1{ }^{\circ} \mathrm{C}$ (Mf). The extrapolated onset temperature of the second detected peak was $2.7^{\circ} \mathrm{C}(\mathrm{Ms}$ ') and extrapolated endset was $33.4^{\circ} \mathrm{C}$ (Mf'). The manifestation of two consecutive peaks during cooling suggests that martensitic transformation occurs in two steps. This could be due to the formation of different martensitic structures [17]. However, on heating related endothermic peaks for reverse martensite transformation (martensite to austenite transformation) were not identified. This result suggests that martensite formed by direct quenching from high temperature is highly stabilized. The stabilization of martensite in many copper-based shape-memory alloys is well-known effect resulting in an increase of the reverse martensitic transformation (As, Af) temperatures [18,19].

DSC thermogram of the second heating/cooling cycle for the as-quenched $\mathrm{Cu}-10 \% \mathrm{Al}-8 \% \mathrm{Mn}-4 \% \mathrm{Ag}$ alloy is given in Fig. 9.

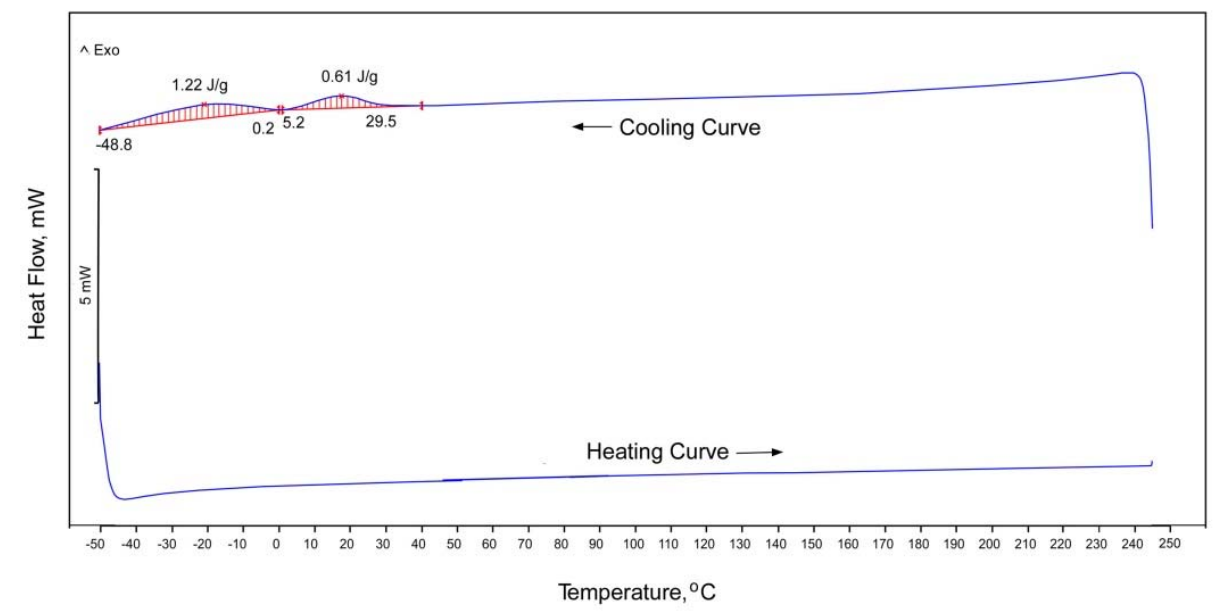

Fig. 9. DSC heating and cooling curves for the as-quenched $\mathrm{Cu}-10 \% \mathrm{Al}-8 \% \mathrm{Mn}-4 \% \mathrm{Ag}$ alloy

Similarly, to the DSC cooling curve for the $\mathrm{Cu}-10 \% \mathrm{Al}-8 \% \mathrm{Mn}$ as-quenched alloy, DSC cooling curve for the $\mathrm{Cu}-10 \% \mathrm{Al}-8 \% \mathrm{Mn}-4 \% \mathrm{Ag}$ as-quenched alloy also included two consecutive exothermic peaks at low temperatures. First detected peak was in the temperature interval from $\mathrm{Ms}=29.5^{\circ} \mathrm{C}$ to $\mathrm{Mf}=5.2^{\circ} \mathrm{C}$. Second detected peak was in the temperature interval from $\mathrm{Ms}{ }^{\prime}=0.2{ }^{\circ} \mathrm{C}$ to $\mathrm{Mf}$ ' $=-48.8^{\circ} \mathrm{C}$. As in the case of $\mathrm{Cu}-$ $10 \% \mathrm{Al}-8 \% \mathrm{Mn}$ as-quenched alloy, peaks related to the reverse martensite transformation were not detected during heating runs.

Mallik and Sampath [11] proposed following empirical equations for prediction of Ms and Mf temperatures of the ternary $\mathrm{Cu}-\mathrm{Al}-\mathrm{Mn}$ SMAs:

$$
M f=360.892-21.393(w t . \% A l)-13.945(w t . \% M n)
$$




$$
M s=397.543-22.762(w t . \% A l)-14.401(w t . \% M n)
$$

For the $\mathrm{Cu}-10 \% \mathrm{Al}-8 \% \mathrm{Mn}$ alloy they give: $\mathrm{Ms}=54.7^{\circ} \mathrm{C}$ and $\mathrm{Mf}=35.4{ }^{\circ} \mathrm{C}$. It can be seen that predicted Ms and Mf values are noticeably higher than experimentally determined values obtained in this study. However, it should be noticed that the applied empirical equations for prediction of Ms and Mf temperatures are very sensitive to the composition of alloys. It could be that the actual composition of the studied alloy varies slightly from the designed one, which was also established by results of EDS analysis presented in Table 1.

\section{Conclusion}

Microstructure and phase transitions of $\mathrm{Cu}-10 \% \mathrm{Al}-8 \% \mathrm{Mn}$ and $\mathrm{Cu}-10 \% \mathrm{Al}-$ $8 \% \mathrm{Mn}-4 \% \mathrm{Ag}$ SMAs were investigated in this work. The microstructure of prepared bulk alloys was investigated in the as-cast state, after homogenization annealing, and after direct quenching into the ice water.

Based on the results of microstructure and thermal analysis following conclusions can be made:

1) The microstructure of the as-cast $\mathrm{Cu}-10 \% \mathrm{Al}-8 \% \mathrm{Mn}$ and $\mathrm{Cu}-10 \% \mathrm{Al}-8 \% \mathrm{Mn}-$ $4 \% \mathrm{Ag}$ alloy is primarily composed of martensite with a small amount of $\alpha$-phase precipitates along the grain boundaries and inside the grains.

2) After homogenization annealing at $850^{\circ} \mathrm{C}$ and slow cooling microstructure of both investigated alloys includes the lath-type phase in the matrix and a considerable amount of irregularly distributed $\alpha$ grains. Silver was evenly distributed among both identified phases.

3) Direct quenching from the $850{ }^{\circ} \mathrm{C}$ into the ice water produce a fully martensitic structure in both investigated alloys.

4) Martensite and austenite transformation temperatures of the as-quenched $\mathrm{Cu}-$ $10 \% \mathrm{Al}-8 \% \mathrm{Mn}$ and $\mathrm{Cu}-10 \% \mathrm{Al}-8 \% \mathrm{Mn}-4 \% \mathrm{Ag}$ alloys were determined using $\mathrm{DSC}$ heating/cooling runs.Two distinct successive exothermic peaks in the temperature interval from about $+30^{\circ} \mathrm{C}$ to $-40{ }^{\circ} \mathrm{C}$ were detected during cooling runs. These results imply that austenite to martensite transformation occurs in two steps during cooling. It could be due to the formation of different martensitic structures. Silver addition does not change martensite transformation temperatures significantly. Direct quenching of alloys into the ice water resulted in stabilization of obtained martensite and reverse martensite transformation temperatures were not identified in the investigated temperature range.

\section{Acknowledgements}

This study was supported by the Ministry of Education, Science and Technological Development, Republic of Serbia, under Project ON 172037. This work has been supported in part by Croatian Science Foundation under the project IP-201409-3405.Also, this study was done in the frame of the bilateral project between University of Belgrade, Technical Faculty in Bor (Serbia) and University of Zagreb, Metallurgical Faculty in Sisak (Croatia), entitled "Razvoj i karakterizacija inovativnih legura sa efektom pamćenja oblika iz sistema $\mathrm{Cu}-\mathrm{Al}-\mathrm{Mn}-\mathrm{Me}(\mathrm{Me}=\mathrm{Ag}, \mathrm{Au}, \mathrm{Ce})$ "'. 


\section{References}

[1] Z.Wang, X. Zu, Y. Fu: Int J Smart Nano Mater, 2 (3) (2011) 101-119.

[2] R. Dasgupta: J Mater Res, 29 (16) (2014) 1681-1698.

[3] M. Blanco, J.T.C. Barragan, N. Barelli, R.D. Noce, C.S. Fugivara, J. Fernández, A. V. Benedetti: Electrochim Acta, 107 (2013) 238- 247.

[4] M. Ahlers: Prog Mater Sci, 30 (1987)135-186.

[5] Y. Sutou, T. Omori, R. Kainuma and K. Ishida: Mater Sci Technol, 24 (8) (2008) 896-901

[6] C. Aksu Canbay, Z. KaragozGenc, M. Sekerci: Appl Phys A,115 (2014) 371-377.

[7] C. AksuCanbay, Z. Karagoz: Appl Phys A, 113 (2013) 19-25.

[8] N. Saunders, A.P. Miodownik, CALPHAD (A Comprehensive Guide), Elsevier, London, 1998.

[9] H. L. Lukas, S. G. Fries, B. Sundman, Computational Thermodynamics, Cambridge University Press, Cambridge, UK, 2007.

[10] J. Miettinen. Calphad, 27 (1) (2003) 103-114.

[11] U.S. Mallik, V. Sampath: J Alloys Compd, 459 (2008) 142-147.

[12] I. Ivanic, S. Kozuh, M. Bizjak, B. Kosec, T. Holjevac Grguric, M. Gojic, Influence of annealing at $900{ }^{\circ} \mathrm{C}$ on the microstructure of $\mathrm{Cu}-\mathrm{Al}-\mathrm{Mn}$ shape memory ribbons, Etikum 2016, Scientific conference with international participation, Novi Sad, Serbia, June 23-25, 2016, pp. 1-4.

[13] W. Cao, S.L. Chen, F. Zhang, K. Wu, Y. Yang, Y. A. Chang, R. Schmid-Fetzer, W. A. Oates: Calphad, 33(2009) 328-342.

[14] U. Sari, I. Aksoy: J Alloys Compd, 417 (2006) 138-142.

[15] G. Lojen, M. Gojić, I. Anžel: J Alloys Compd, 580 (15) (2013) 497-505.

[16] R. Dasgupta, A. K. Jain, P. Kumar, S. Hussein, A. Pandey: J Mater Res Technol, 3 (3) (2014) 264-273.

[17] R. Gastien, C. E. Corbellani, M. Sade, F. C. Lovey. Acta Mater, 53 (2005) 16851691.

[18] S. Kustov, J. Pons, E. Cesari, J. Van Humbeeck: Acta Mater, 52 (2004) 4547-4559

[19] T. Suzuki, R. Kojima, Y. Fujii, A. Nagasawa: Acta Metall, 37 (1) (1989) 163-168.

(c) (i) Creative Commons License

This work is licensed under a Creative Commons Attribution 4.0 International License. 